\title{
Importance of legal regulations resulting from technical harmonization in the European Union for improvement of work safety of farmers in Poland
}

\author{
Agnieszka Żywicka ${ }^{1, A-D \oplus}$, Piotr Choina ${ }^{2, B-F \oplus}$, Mirosław Jerzy Jarosz ${ }^{3, D, F} \oplus$ \\ 1 Jan Kochanowski University, Kielce, Poland \\ 2 Department of Medical Anthropology, Institute of Rural Health, Lublin, Poland \\ ${ }^{3}$ University of Economics and Innovation, Lublin, Poland \\ A - Research concept and design, B - Collection and/or assembly of data, C - Data analysis and interpretation, \\ $D$ - Writing the article, $E$ - Critical revision of the article, F - Final approval of the article
}

Żywicka A, Choina P, Jarosz MJ. Importance of legal regulations resulting from technical harmonization in the European Union for improvement of work safety of farmers in Poland. Ann Agric Environ Med. 2021; 28(3): 378-384. doi: 10.26444/aaem/141625

\begin{abstract}
Introduction and objective. Accidents exert a negative effect on the quality and standard of living of rural inhabitants, especially when they make it impossible to continue work on a farm, or this work may be performed only to a limited extent. The creation of effective legal mechanisms which would guarantee the safety of operation of machinery is a crucial issue, it is of a preventive character and considerably limits the number of accidents. Approximately 16.1 million people live in the rural areas and around 2.3 million work in the agricultural sector, which represents $14.5 \%$ of all labour in Poland in 2019.

Objective. The aim of the study was to evaluate the legal regulations resulting from the directives of technical harmonization in the European Union for improvement of safety of work with the use of agricultural machinery in Poland.

Materials and method. The method was critical analysis of legal acts in effect, court rulings, and statistical data concerning accidentsoin farms, made available by the Agricultural Social Insurance Fund (KRUS).

Brief description of the state of knowledge. As a result of Poland's membership of the European Union, rural areas were covered by globalization processes and single market rules, within which there function legal mechanisms of safety and quality of products.

Conclusions. Analysis of the 16 years of Poland's membership of the EU, resulted in positive results being observed in the use of the directives of technical harmonization, especially in reducing the number of accidents involving agricultural machinery. However, this improvement may result from using newly-purchased, modern and safer agricultural machinery covered by the conformity assessment, and preventive actions carried out by the Agricultural Social Insurance Fund. An impact of other factors, not analysed in the study, cannot be ruled out.
\end{abstract}

\section{Key words}

farmers, work safety, technical harmonization

\section{INTRODUCTION}

With more than a third of the world's labour force employed in agriculture, after services, this sector is the second greatest source of employment worldwide. The population of Poland is 38.4 million, of which 15.3 million live in rural areas, of whom around 2.3 million people work in the agricultural sector, which represents $14.5 \%$ of all labour in Poland [1]. Agriculture involves a wide range of different types of machinery, animals, plants and products, working in both indoor and outdoor environments under widely varying geographic and climatic conditions. Agriculture, in fact, is one of the most hazardous of all sectors, and many agricultural workers sustain occupational accidents and ill health each year. The contributory causes of such accidents and ill health are many, but often include:

- working with machines, vehicles, tools and animals; - exposure to excessive noise and vibration;

Address for correspondence: Piotr Choina, Department of Medical Anthropology, Institute of Rural Health, ul. Jaczewskiego 2, 20-090 Lublin, Poland

E-mail: choina.piotr@imw.lublin.pl

Received: 25.06.2021; accepted: 26.08.2021; first published: 03.09.2021
- slips, trips and falls from heights;

- lifting heavy weights and other work giving rise to musculoskeletal disorders;

- exposure to dust and other organic substances, chemicals, and infectious agents;

- other working conditions common to rural environments, such as exposure to extreme temperatures, inclement weather and attacks by wild animals [2].

Accidents while performing agricultural tasks are an important problem from the health, social, and legal aspects. These events take place in various circumstances. Some of them are caused by the improper use of agricultural machinery, their poor technical state, or non-compliance of these devices with technical requirements. Accidents exert a negative effect on the quality of life and standard of living of rural inhabitants, especially in situations when, as a result of the event, further work on a farm is impossible, or this work may be performed only to a limited extent. This negatively affects not only the health but also the standard of living of the person who has suffered an accident, but also the remaining household members on the farm, significantly worsening 
future prospects due to reduced earning opportunities; the situation becomes even more complicated in the case of a fatal event.

Child labour is also more prevalent in agriculture than in any other economic sector, accounting for approximately $70 \%$ of child labour worldwide. Moreover, since many children below the age of employment live on farms, the risk to them of accidents and diseases is significantly increased [2].

For many years in Poland, the problem has been signalled of adequate and effective legal regulations in the area of farmers' social insurance, whereas the problem concerning legal conditioning of the safety of machines used in agriculture is still undertaken too rarely. However, the creation of effective legal mechanisms which would guarantee the safety of operating of machinery is crucial, because it is of a preventive character eliminating or considerably reducing the number of events. In the conditions of Poland's membership of the European Union this situation has changed because the Polish rural areas were also covered by globalization processes and single market rules, within which there function legal mechanisms of safety and quality of products created on the European Union level, in the form of directives of technical harmonization. The concern of the Polish legislator focuses around the efficient implementation of directives to the national legal order, and primarily the creation of internal legal and organizational structures left for the internal decision of the Member States which guarantee safety.

In the context of the presented information, it is vital to answer the question whether these legal regulations can be a factor improving work safety when working with agricultural machinery.

\section{OBJECTIVE}

The main aim of the study is to evaluate the significance of the legal regulations regarding technical harmonization in the European Union for improvement of safety of work with the use of agricultural machinery in Poland. The secondary objectives are to present a normative definition of a work accident in agriculture work, along with the available data regarding such accidents, and to present legal conditions regarding the safety of agricultural machinery use.

\section{MATERIALS AND METHOD}

The research materials were publications of legal acts in effect, court rulings, and statistical data concerning accidents in private farming made available by the Central Office of the Agricultural Social Insurance Fund. The method applied was critical analysis in relation to the normative definition of occupational accident and statistical data pertaining to such events in private farming, and selected issues concerning farmers' social insurance. Legal conditioning of the safety of machinery was especially analyzed as a factor exerting an effect on the reduction of accident risk while performing agricultural work.

Accident while conducting agricultural work activities. The legal definition of an accident during agricultural work is contained in Article 11 of the Farmers' Insurance Act $^{1}$ where an accident during agricultural work is considered a sudden event as a result of an external cause which occurred while conducting agricultural activities, or in connection with these activities:

1) on the farm which the insured manages or is constantly working, or in a household directly connected with this farm, or:

2) on the way of the insured from lodging to farm, referred to in point 1 , or on the way back, or:

3) during performing work outside the farm area, referred to in point 1 , ordinary agricultural activities, or in connection with conducting these activities, or:

4) on the way to the site of conducting activities referred to in point 3 , or on the way back.

The legislator defines occupational accident in agriculture very widely, which is also confirmed by the rulings of the Supreme Court which facilitates farmers pursuing their claims within social insurance. In the judgement of 12 January 2001, the Supreme Court stated that an accident at agricultural work is a sudden event caused by an external cause related to the performance of activities which serve the conducting of agricultural activity, or remain in a temporal, causal or functional relationship with its performance, also outside the farm area. ${ }^{2}$ Ordinary activities associated with running a farm are the activities indispensable for the proper functioning of a farm, so closely associated with farming that without them the farm could not function properly. The rule was expressed to qualify as protected accidents all the events which were caused by an external cause, and remained in connection with performance outside the farm area of typical agricultural activities, i.e. the activities used to conduct agricultural activity or remain in connection with the performance of these activities ${ }^{3}$. In the context of the problem undertaken in the presented study, an important external cause will be, among others, improper technical state of agricultural machinery, as indicated by the data by the Agricultural Social Insurance Fund (KRUS).

According to the statistical data by KRUS, in 2020, farmers reported to the KRUS 10,974 accidents, which was 2,667 (19\%) les than in 2019; 7,872 one-off compensations were paid for damage to health or death due to an agricultural accident, by $2,423(23.5 \%)$ less than in 2019; 35 fatal accidents were registered, by $22(38.6 \%)$ less than in 2019. It is worth paying attention to the types of occupational accidents - those which occurred as a result of the use of machines and equipment in agriculture occupied the second place. The largest number of people became victims to accidents due to: 'fall of persons' - 3,718 (47.2\% of all one-off compensations paid), 'being caught or hit by moving parts of machines and devices" - 958 (12.2\%),'blows, crushes, or animal bites' - 958 (12.2\%).

From 1993, the accident rate (number of accidents per 1,000 insured) decreased from 24.6 down to 6.6 (by 14.4) in 2020. The number of accidents reported also decreased from 66,000 to 10,974 (more than 6 times fewer), and the number of one-off compensations paid - from 42,000 down

1. Act of 20.12.1990 in the matter of farmers' social insurance, Journal of Laws 2021, Item 266.

2. II UKN 176/00 - judgment of the Supreme Court / Chamber of Labour of 12.01.2001.

3. II UK 361/03 - judgment of the Supreme Court - Chamber of Labour of 13.05.2004. 
to 7,872 , including those arising from fatal accidents - from 286 to $35[3,4]$.

However, the above-mentioned data should be interpreted in two ways. On the one hand, a decrease in the number of accidents occurred as a result of legal changes that came into force on 2 May to some other acts $[5,6]$. The regulations introduced were intended to limit the right to granting oneoff compensation only to persons subject to the farmers' social insurance. According to the wording of Article 10 of the Act, one-off compensation is only available to 'the insured who has suffered permanent or long-term damage to health as a result of an accident at agricultural work or agricultural occupational disease' $[5,6]$. In consequence, accident compensation is not applicable to retirement pensioners, disability pensioners with a pronounced inability who live independently, and children aged up to 16 . In this way, a decrease of approximately $30 \%$ was obtained in the number of the reported accident claims. This was the approximate number of one-off accident compensations paid to noninsured persons who were entitled to the benefit as close relatives of an insured farmer, and who help with maintaining agricultural activity (close relative of a farmer, in order to obtain the right to one-off compensation due to accident at agricultural work, must be insured against an accident at work).

On the other hand, during the period from 1993 until today, important changes have taken place in the structure of persons insured by the KRUS (Tab. 1) [5, 6]. These changes are due for demographic reasons, and additionally are the result of changes in legal regulations. A leap in the change in the structure is noticeable between 2004-2005, when the number of persons receiving disability pensions decreased more than two-fold, from 745,917 down to 371,805 (a decrease by 374,112 ), and the number of the insured who received retirement pension increased from 962,718 up to $1,272,865$ (an increase by 310,147 ). This results from the legal regulation of the Act of 2004, which obliges the KRUS to each-time conversion of a disability pension into retirement in the case when the pensioner has reached retirement age and had a 20 -year insurance period (females) or a 25-year insurance period (males). This procedure, however, blurred the image of reality: it was how many had lost capability for work even before reaching this age [7]. It is also noteworthy that during these years there occurred a reversal of the rate between the number of beneficiaries (disability or retirement pensions) and the number of those insured by the KRUS. In 1996, this rate was 1.45 , whereas in 2020 its value was 0.92 . In absolute numbers, this means a decline in the number of people receiving disability or retirement pensions from $2,027,118$ to only $1,083,411$. With the number of persons insured by the KRUS remaining on the level of approx. 1,173,236, this is evidence of the serious demographic changes which have taken place during the last 24 years in the population working on Polish family farms, and this also could not remain without influence on the frequency and character of accidents at work.

According to the data by the KRUS, during the last 24 years no essential changes have been observed in the structure of the causes of accidents in Polish private farming; however, in the categories associated with the use of technical means (vehicles, equipment and machinery) downward tendencies may be noted (Tab. 2) $[3,5,8,9]$. In particular, the percentage of accidents classified as 'being caught or hit by moving parts
Table 1. Number of the insured and beneficiaries during 1996-2020

\begin{tabular}{|c|c|c|c|c|}
\hline Year & $\begin{array}{c}\text { Disability } \\
\text { pensioners } \\
\text { A }\end{array}$ & $\begin{array}{c}\text { Retirement } \\
\text { pensioners } \\
\text { B }\end{array}$ & $\begin{array}{c}\text { Insured } \\
\text { C }\end{array}$ & $\begin{array}{c}\text { Beneficiaries/ } \\
\text { Insured } \\
\mathrm{A}+\mathrm{B} / \mathrm{C}\end{array}$ \\
\hline 1996 & 814,845 & $1,212,273$ & $1,398,260$ & 1.45 \\
\hline 1997 & 825,244 & $1,175,333$ & $1,419,493$ & 1.41 \\
\hline 1998 & 829,578 & $1,139,265$ & $1,418,928$ & 1.39 \\
\hline 1999 & 831,057 & $1,097,857$ & $1,426,393$ & 1.35 \\
\hline 2000 & 831,530 & $1,055,728$ & $1,444,202$ & 1.31 \\
\hline 2001 & 827,036 & $1,014,791$ & $1,484,934$ & 1.24 \\
\hline 2002 & 822,915 & 974,951 & $1,541,129$ & 1.17 \\
\hline 2003 & 819,285 & 936,027 & $1,581,747$ & 1.11 \\
\hline 2004 & 745,927 & 962,718 & $1,584,487$ & 1.08 \\
\hline 2005 & 371,805 & $1,272,865$ & $1,563,869$ & 1.05 \\
\hline 2006 & 339,195 & $1,246,775$ & $1,604,174$ & 0.99 \\
\hline 2007 & 319,829 & $1,210,405$ & $1,609,644$ & 0.95 \\
\hline 2008 & 302,154 & $1,175,751$ & $1,584,884$ & 0.93 \\
\hline 2009 & 287,757 & $1,137,709$ & $1,570,617$ & 0.91 \\
\hline 2010 & 278,019 & $1,096,321$ & $1,543,574$ & 0.89 \\
\hline 2011 & 270,043 & $1,056,307$ & $1,523,168$ & 0.87 \\
\hline 2012 & 263,546 & $1,021,927$ & $1,501,190$ & 0.86 \\
\hline 2013 & 259,973 & 985,507 & $1,478,328$ & 0.84 \\
\hline 2014 & 259,886 & 951,542 & $1,448,442$ & 0.84 \\
\hline 2015 & 259,955 & 943,019 & $1,393,263$ & 0.86 \\
\hline 2016 & No data & No data & No data & No data \\
\hline 2017 & 256,872 & 918,443 & $1,270,525$ & 0.92 \\
\hline 2018 & 243,036 & 914,389 & $1,233,685$ & 0.93 \\
\hline 2019 & 236,703 & 883,920 & $1,199,285$ & 0.93 \\
\hline 2020 & 229,672 & 853,740 & $1,173,236$ & 0.92 \\
\hline
\end{tabular}

Source: KRUS $-[3,5,8,9]$

Table 2. Structure of causes of accidents in private farming in Poland

\begin{tabular}{lcccc}
\hline Cause of accident & 1995 & 2018 & 2019 & 2020 \\
\hline fall of persons & $48.7 \%$ & $48.1 \%$ & $48.3 \%$ & $47.2 \%$ \\
\hline fall of objects & $5.9 \%$ & $6.0 \%$ & $6.50 \%$ & $5.5 \%$ \\
\hline $\begin{array}{l}\text { contact with sharp hand tools and other } \\
\text { sharp objects }\end{array}$ & $7.4 \%$ & $4.6 \%$ & $4.6 \%$ & $4.8 \%$ \\
\hline $\begin{array}{l}\text { being struck or crushed by materials and } \\
\text { objects transported mechanically or manually }\end{array}$ & $4 \%$ & $2.0 \%$ & $1.9 \%$ & $2.1 \%$ \\
\hline $\begin{array}{l}\text { driving over, hitting, being caught by a } \\
\text { means of transport in motion }\end{array}$ & $3.1 \%$ & $2.0 \%$ & $1.4 \%$ & $1.5 \%$ \\
\hline $\begin{array}{l}\text { being caught or hit by moving parts of } \\
\text { machines and devices' }\end{array}$ & $13.4 \%$ & $12.3 \%$ & $11.9 \%$ & $12.2 \%$ \\
\hline \begin{tabular}{l} 
'blows, crushes, or animal bites' \\
\hline fire, explosion, effect of forces of nature
\end{tabular} & $0.8 \%$ & $11.2 \%$ & $12.0 \%$ & $12.2 \%$ \\
\hline effect of extreme temperatures & $1.1 \%$ & $0.5 \%$ & $0.6 \%$ & $0.5 \%$ \\
\hline \begin{tabular}{l} 
effect of hazardous materials \\
\hline sudden illness
\end{tabular} & $0.4 \%$ & $0.1 \%$ & $0.1 \%$ & $0.1 \%$ \\
\hline \begin{tabular}{l} 
other events \\
\hline Source
\end{tabular} & $5.5 \%$ & $11.0 \%$ & $11.2 \%$ & $12.2 \%$ \\
\hline
\end{tabular}

Source: KRUS. $[3,5,8,9]$.

of machines and devices' decreased since 1995 from 13.4\% to $12.1 \%$ in 2020 . The percentage of accidents classified as 'driving over, hitting, being caught by a means of transport in motion' also decreased during this period from $3.1 \%$ down to $1.5 \%$; and similarly, the percentage of accidents caused by 
'being struck or crushed by materials and objects transported mechanically or manually' declined from $4 \%$ down to $2.1 \%$. In turn, during the analyzed period, an increase was observed in the percentage of accidents caused by 'other events' - from $4.0 \%$ in 1995 to $12.2 \%$ in 2020 . Table 2 presents the structure of accidents at the beginning and during the last three years of the analyzed period.

The study on the diversity of agricultural accident statistics in European countries showed large discrepancies in the data published by Eurostat, compared to the results published in the national statistics of agricultural accidents. in 2013, Germany reported 89 fatalities to Eurostat (accident rate 2.3 / 100,000 people working in agriculture), while the national data reported as many as 160 fatalities (accident rate 16.3 / $100,000)$. In contrast, Poland, with a similar land area and five times as many farms and workers as Germany, reported in Eurostat only four deaths in agriculture, while domestic sources showed 77 deaths in 2013. Finland and Sweden, with similar agricultural structures, had a tenfold difference in reporting accidents to Eurost: Finland reported 5,331 and Sweden 554 total accidents in agriculture. These examples illustrate the wide variation in agricultural accident statistics. There can be many reasons for this: a) different structure of farms, b) use of hired workers, c) differences in the grading of accidents due to the cause of the accident, d) different criteria for recognizing or not recognizing an accident, and e) different interpretations of accidents by insurers. [10]. Analysis of the statistical data of European countries on accidents in agriculture showed that similar categories of data reporting to the Polish system are also presented by the United Kingdom. For comparison, in the United Kingdom in 2020, accidents related with agricultural machinery ('contact with machinery') constituted $10 \%$, similar to Poland - $12.2 \%$; however, 'fall of persons' ('slip, trip, fall on same level') constituted $20 \%$, i.e. it was twice lower than in Poland $47.2 \%[3,11]$.

Despite the fact that year by year accident rates while performing agricultural work gradually decrease, it still remains an important problem from the aspect of farmers' health, as well as in the context of confirmation of occupational accidents and payment of compensations in this respect. Agriculture is one of the most accident prone branches of production, not only in Poland, but worldwide. High risk of accident events on farms results from the complexity of the work environment of a farmer (among others, the necessity to perform various activities requiring different skills, changeable weather conditions, periodical accumulation of work), and many hazards occurring at the workplace [12]. In this respect, not only the organization of health services and medical care will be important, but also good legal provisions regulating farmers' health insurances, primarily those defining minimum safety requirements for agricultural machines.

Legal safety regulations for agricultural machinery conformity assessment systems. Poland's membership of the European Union exerts an effect on the successive reduction in the number of accidents in agriculture in Poland - especially with respect to accidents associated with the use of widely understood agricultural techniques - machines and devices implemented to the market as new. This is connected with the implementation of legal acts regulating the safety of agricultural machinery into the Polish domestic legal order. Increased investments in agriculture result in the reduction in the number of accidents, due to the European Union funds farmers can afford to purchase modern, safer machinery covered by the conformity assessment, which is translated, among other things, into a decrease in the number of accidents.

The problems of the safety of machinery used in agriculture are regulated at the EU level in the technical harmonization directives. The principle of the 'New Approach' to technical harmonization and normalization introduced in the European Union in 1985 has led to determination of the essential requirements, whereby a product placed on the Community market must satisfy the exercising of the right to free movement within the Community. The New Approach directives determine not only the basic requirements related to guaranteeing the safety of persons and property, animals, and the environment during the use of products [13], but also detailed technical requirements (specifications) with which the product must comply, contained in standards harmonized with the given directive. It should be emphasized that the application of harmonized standards is optional, and the producer may use other technical specifications. However, only the use and satisfaction of the requirements of harmonized standards allows the so-called presumption of conformity that the product complies with the essential requirements, and may exercise the right of free movement on the Community market. All these rules guarantee that only safe products would participate in the flow of goods [14]. Most often, according to the type of hazards occurring during the operation of the device (machine), it happens that the device is simultaneously subject to two or more directives ${ }^{4}$.

As noted above, technical harmonization imposes an obligation on machine manufacturers to conduct quality control on products entering the European market as part of conformity assessment procedures $[15,16]$; thus, it is worth generally presenting the essence of this legal mechanism and its implications with respect to farmers' safety.

The concept of 'conformity assessment' in the normative sense is primarily a category of substantive law. Conformity assessment is the act of applying the law of the relevant entity to the product's compliance with specific normative requirements. The compliance assessment system consists of regulations provisions setting out the essential and specific requirements for the products, and regulations and standards specifying the activities of entities participating in the process of conformity assessment, which are an exemplification

4. In the case of agricultural machinery, the basic applicable Community legal act is Directive 2006/42/EC of the European Parliament and of the Council of 17.05.2006 on machinery, amending Directive 95/16/EC, Journal of Laws, L 157 of 09.06.2006, p. 24, consolidated version, amended by Regulation (EC), No. 596/2009 of the European Parliament and of the Council of 18.06.2009. Journal of Laws L 188 of 18.07.2009, p. 14, and Directive 2009/127/EC of the European Parliament and of the Council of 21.10.2009, Journal of Laws, L. 310 of 25.11.2009, p.. 29. The national legal act implementing the machinry directive is the regulation by the Minister of Economy of 21.10.2008 in the matter of essential requirements for machinery, Journal of Laws, 2008, No. 199, Item. 1228, amended by the Regulation by the Minister of Economy of 13.06.2011 amending the regulation in the matter of essential requirements for machinery, Journal of Law, 2011, No.124, Item 701. In turn, the framework of the conformity assessment system was standardized in the Act of 30.08.2002 about the conformity assessment system, i.e. Journal of Laws, 2017, Item 1226, and the Act of 13.04.2016 in the matter of r. o conformity assessment and market surveillance systems, Journal of Laws, 2017, Item 1398. 
of technical harmonization. This system covers both the checking of compliance of the products with essential and other requirements, and proceedings regarding products placed on the market or put into service, which are not in accordance with the essential or other requirements. The conformity assessment system with essential requirements is a legal structure that informs about relationships between the product and normatively specified requirements as a result of conducting the process of comparing product properties with a specific pattern [17]. The reference plane in this comparison process are relevant verification criteria - essential, specific or other requirements, the source of which are technical standards. Compliance with these requirements by the manufacturer is intended to lead to the effective protection of public interest, taking into account normatively set criteria to this protection, in order to guarantee product safety [18]. In the conformity assessment system participate the producers, their authorized representatives, importers, certification bodies, inspection bodies and laboratories.

The subjects of conformity assessment are products placed on the internal market. The product category includes only movable items - as well as agricultural machinery, and the key condition to carry it out is the intention of or actual placing of the product on the market in the European Union, the origin of the product being immaterial. Subjecting the product to assessment is mandatory before placing it on the market. The timing of placing the product on the market or its use is of paramount importance, both for entrepreneurs and market surveillance authorities (from now on, the authorities have the competence to undertake control activities), as well as for the users. Based on Article 3a of the Act on compliance assessment and market surveillance systems, the control applies to products already on the market or put into service within the EU. The product liability is based on this basis. According to Article 45 of the Act in the matter of conformity assessment system, the responsibility is borne by the person who places the products on the market or puts them into service.

In the opinion of the European Commission, the placing on the market takes place at the moment when the product is made available for the first time within the Single Market. It is considered that this takes place when the product is transferred after manufacture or offered for distribution, with the intention of distribution or use in the European Union. This includes physical transfer of the product or transfer of ownership. The concept of 'placing on the market' refers to each individual product, and not to the type of product, irrespective of whether the product is manufactured in series or as a single unit. 'Putting into service' is handled as using the product for the first time in the European Union. According to the directives, conformity assessment is carried out before placing on the market or putting the product into service. Most products are on the market before being put into service - conformity assessment must be carried out before placing on the market. However, some products are not on the market - for instance, they are manufactured to the recipient's order and delivered directly by the manufacturer. In this case, the provisions of the directives specify that conformity assessment must be carried out before putting into service [15].

Placing on the market and putting into service are the first steps in the process of supplying a product on the Community market in respect of new products. In the Act in the matter of the conformity assessment system, the semantic range of the terms 'placing on the market' and 'putting into service' were combined. From Article, Point 2 of the Act, it follows that there functions one term - placing on the market' - meaning the first time a product is handed over to the user, consumer or seller by the manufacturer, its authorized representative or importer. The definition includes both the delivery of goods to the seller (then the product is placed on the market) and handing over to the user (then the product may not hit the market, but be sent directly from the manufacturer to the user, i.e. put into service).

Products which legally - after carrying out conformity assessment are on the market in any country in the Community - are subject to the law of free movement in accordance with the rules in Articles 28 and 30 TFUE. ${ }^{5}$ Conformity assessment also covers products imported from outside the EU - before being placed on the market - and applies to both new and used products. After being released for free circulation within the meaning of the customs legislation, when they obtain the status of Community goods these products also enjoy the rightto free movement [16].

Conformity assessment may be carried out in various ways. Regulations implemented into Polish law, individual New Approach directives, specify the appropriate modes of procedures. In the light of Article 7 of the Act in the matter of conformity assessment in the Polish system, there are several methods (modules and their variants), based on three essential procedures:

- conformity assessment conducted by the producer or its authorized representative;

- a notified body - independent of the supplier and the recipient, assesses conformity of the product with the essential requirements;

- a notified certification body makes certification - issues a certificate of conformity to the manufacturer or its authorized representative.

Conformity assessment procedures may concern either the product itself or the design and production process, and may consist in the following:

- internal design and production control by the manufacturer;

- type examination by a third party (notified body) in combination with internal production control by the manufacturer;

- type or design examination by a third party (notified body) in combination with its approval of the product or production quality assurance systems, or with product verification by a third party;

- third party design and production verification;

- approval of the full quality control system by a third party.

Performing product conformity assessment is the responsibility of the manufacturer, who bears full responsibility for its product; therefore, it must control (directly or indirectly) the entire product creation process and ensure the meeting of the requirements specified by regulations. The manufacturer cannot assign responsibility for a defective or dangerous product to a subcontractor or notified body. The type of manufacturer's obligations regarding conformity assessment depends primarily on the module applied.

5. Treaty on the Functioning of the European Union, consolidated version Journal of Laws. UE C 326 of 26.10. 2012, P. 0001-0390. 
The conformity assessment procedure boils down to the following stages pursued by the producer. Firstly, the producer is obliged to check whether the product is subject to the regulations of at least one of the New Approach directives, and check the essential requirements set out therein. Secondly, it must perform analysis of the risk created by the product, and prepare the list of the essential requirements relevant to the product, which relate to identified threats, and subsequently become familiar with the content of harmonized European standards relevant to the product. The third step is the preparation of technical documentation by the entrepreneur, containing the elements required by the directive, which should be kept in most cases for 10 years. The last stage is completing the conformity assessment procedure specified for a given product in the directive, and preparation and signing of the CE declaration of conformity by the manufacturer. The result of these activities is the $\mathrm{CE}$ marking on the product [19].

State policy regarding the agricultural machinery control system, and informing farmers about the safety of agricultural machinery. From the point of view of farmers, using machinery covered by the conformity assessment process means the control of machines put into service, and appropriate state information policy on dangerous or life-threatening goods. Farmers, as final users, have the right to expect their machinery to meet safety standards. The control of products subject to conformity assessment is an essential element in the implementation of the New Approach directives in each European Union country. The purpose of the control system is to ensure that only products that meet the essential requirements are sent to users in the EU, regardless of where they were produced. The Polish system of products control with respect to agricultural machinery was created on the basis of standards in force in the EU, especially European Commission guidelines contained in the 'Blue Guide' [15] implemented in 2004 by the Act of 30 August in the matter of conformity assessment system. A key role was entrusted by the Polish legislator to the President of the Office of Competition and Consumer Protection, as a central government administration body competent in matters of competition and consumer protection on the national level. The activities of bodies involved in controls consists primarily in controlling the products put into service, and seeking products which do not meet the requirements. These authorities are also required to take the necessary corrective actions (eliminating hazards related with the products) [15]. For this reason, this also includes products placed on the market or use that meet the requirements, which during use display dangerous features.

A no less important role is played by the information policy of the State on the nature of conformity assessment. In order that legal regulations fulfil their function, legal awareness of the public is necessary. In this respect, information campaigns are important, carried out by the office of Competition and Consumer Protection in the media and on the Internet, an example of which is the Register of Dangerous Products [20]. The programmes by the KRUS are also no les important, as well as the involvement of social institutions and organizations. It is worth mentioning, for example, a programme of certification of the most dangerous agricultural machinery - the KRUS Safety Sign. The promotion of safe products falls within the preventive actions of the KRUS, aimed at reducing the number of accidents at work, and farmers' occupational diseases. Within the period of 25 years, the President of the KRUS issued 73 permissions to marking 235 products with the KRUS Safety Sign 'B', and awarded 70 distinctions during the AGROTECH Fair [21]. A similar role is played by the competition 'Safe Farm' organized annually for farmers by the KRUS in association with the Minister of Agriculture and Rural Development and the National Labour Inspectorate [22].

Actions undertaken by the KRUS are very important since the entry into force of the Act of 20 December 1990 in the matter of farmers' social insurance (Journal of Laws, 2017, Item 2,336), which in Article 56 enables the President of the KRUS to reimburse suppliers of products and services for agriculture, the defectiveness of which was the sole or main cause of accidents at agricultural work or occupational disease, the insurance benefits paid to the injured farmers. During the period 1993-2004, the KRUS questioned 350 types of machines and devices, the defects of which were the main or accompanying user errors that caused the accidents. During the above-mentioned period, the KRUS questioned five faulty services [23]. Within the subsequent two years, the KRUS questioned a further 120 products [24] (the result of termination of proceedings initiated before Poland joined the EU, and prior to the implementation of new requirements regarding the testing and certification of products for the Safety Sign 'B'. In subsequent years, the number of recourse proceedings and preventive proceedings conducted by the KRUS decreased. In 2007, two recourse proceedings and one preventive proceeding were conducted [25]. No new proceedings were initiated in 2008 [26]. In 2009, no accidents were reported caused by a machine design defect or faulty service. The recourse initiated in 2006 has been completed [27]. In 2010, two recourse proceedings were initiated, and in 2011 no new proceedings were reported [28]. Similarly, during the period 2012-2013, no new recourse proceedings were reported against machine or device manufacturers or units providing services for agriculture [29]. In 2014, one recourse proceeding was initiated against a company providing a service for agriculture [30]. During the following years no recourse proceedings were introduced.

Based on the above-quoted information, it may be presumed that legal regulations introduced in 2004 concerning product testing and certification for the Safety Sign 'B' improved the technical state of machines newly placed on the market which, in consequence, improved the state of safety of farmers regarding the use of agricultural machinery. The activity of the KRUS concerning the organization of trainings is very important. In 2020, the KRUS organized 2,768 shows for nearly 116,500 people. During the shows were presented, among others, the safe way to use agricultural machinery and devices [3]. Within the scope of pursuing the Council Regulation (EC) No. 1698/2005 of 20 September 2005, Article 24 , paragraph 1 point $b$, in 2009 , a publication containing 131 pages entitled 'Work Safety and Occupational Hygiene on Farms' was issued by the mutual efforts of the KRUS, the Central Institute of Labour Protection, Ministry of Agriculture, Agricultural Advisory Centre, Agricultural Property Agency, and the National Labour Inspectorate. This is a guide for agricultural advisors, the contents of which are imparted during training meetings. This publication was updated in 2020 [2,31]. 


\section{CONCLUSIONS}

The decrease observed in the number of accidents registered by the KRUS, one-off compensations paid, and a decrease in accident rates may evidence an improvement in the state of work safety among persons insured by the KRUS. Increasing the safety of agricultural machinery, directly resulting from the legal regulations standardizing minimum technical requirements regarding product safety in the field of conformity assessment, undoubtedly contributed to this state of affairs.

The considerations presented in this study confirm, in some measure, the thesis posed at the beginning concerning the importance of legal mechanisms in the area of safety of the use of machinery as instruments of a preventive character, with respect to potential accidents in agriculture. A 16 year period of using harmonised Polish and EU regulations, allows observation of positive results in the application of conformity assessment systems for agricultural machinery, which may be observed, among others, as no new recourse proceedings have been conducted by the KRUS. However, this considerable improvement noted in the area of work safety on family farms, may result more from using newly purchased, modern and safer agricultural machinery covered by the conformity assessment.

Other important factors are the preventive actions carried out by the KRUS, based on analysis of the causes and circumstances of accidents and occupational diseases, the directions of these actions, and the variety of their forms, considerably contributed to the elimination of many accident risks, and consequently exerted a positive effect on the standard of living of rural inhabitants. However, the impact of other factors not mentioned in the study, cannot be ruled out. The determination of such factors would require further, empirical research.

\section{REFERENCES}

1. GUS. Rocznik Statystyczny Rolnictwa 2020. GUS, Warszawa 2020.

2. ILO. Safety and health in agriculture. ILO code of practice. International Labour Office - Geneva: ILO, 2011, ISBN 978-92-2-124970-2

3. KRUS. Prewencja, Statystyki: Wypadki przy pracy i choroby zawodowe rolników oraz działania prewencyjne KRUS w 2020 roku. Warszawa 2021. https://www.krus.gov.pl/fileadmin/moje_dokumenty/ dokumenty/prewencja/statystyki/2021/Komunikat_o_wypadkach_i_ chorobach_w_2020_roku_003.pdf (access: 7.06.2021 r.)

4. KRUS - Centrala. Kasa rolniczego ubezpieczenia społecznego Informacje podstawowe. Warszawa 2021.

5. KRUS - Centrala. Kasa rolniczego ubezpieczenia społecznego Informacje podstawowe. Warszawa 2016.

6. KRUS. Ubezpieczenia w rolnictwie. Materiały i Studia. 2012; 44: 38.

7. KRUS. Ubezpieczenia w rolnictwie. Materiały i Studia. 2009; 34: 49.

8. KRUS. Broszura statystyczna pt. „Komunikat o wypadkach i chorobach zawodowych rolników w 2018 r”. https://www.krus.gov.pl/ fileadmin/moje_dokumenty/dokumenty/prewencja/statystyki/2019/ Komunikat_o_wypadkach_i_chorobach_w_2018_d.pdf (access: 7.06.2021 r.)

9. KRUS. Broszura statystyczna pt. „Komunikat o wypadkach i chorobach zawodowych rolników w 2019 r". https://www.krus.gov.pl/ fileadmin/moje_dokumenty/dokumenty/prewencja/statystyki/2020/ Komunikat_o_wypadkach_i_chorobach_2019_r.pdf (access: 7.06.2021 r.)

10. Merisalu E, Leppala J, Jakob M, Rautiainen RH. Variation in Eurostat and national statistics of accidents in agriculture. Agronomy Research 17(5), 1969-1983, 2019, https://doi.org/10.15159/AR.19.190

11. Health and Saftey Executive. Health and safety in the Agriculture. forestry and fishing sector in Great Britain, HSE 2020. www.hse.gov. uk/statistics (access: 04.09.2020 r.)

12. Kuta $Ł$. Wpływ inwestycji w gospodarstwach rolnych na poprawę bezpieczeństwa rolników. Inżynieria rolnicza 2013, Z. 3(145) T.1.

13. Klembalska K. Badania bezpieczeństwa elektrycznych maszyn i urządzeń rolniczych, leśnych i ogrodniczych, Zeszyty Problemowe Maszyny elektryczne nr 72/2005.
14. Żywicka A. Egzemplifikacje prawne wpływu harmonizacji technicznej na rozwój sektora przedsiębiorczości w Unii Europejskiej. In: Wpływ prawa Unii Europejskiej na gospodarkę i samorząd terytorialny państw członkowskich. Ganczar M, Król J, Szewczak M, editors. Łódź; 2016.

15. UE, Blue guide 2016 - przewodnik po wymogach CE dla produktów w UE, Dz. Urz. UE 2016/C 272/01. z dn. 26 lipca 2016 r. www.europa. eu.int/comm/enterprise/ newapproach/newapproach.htm (access: 1.03.2018 r.)

16. Urząd Ochrony Konkurencji i Konsumentów. Polski system oceny zgodności i kontrola wyrobów podlegających dyrektywom nowego podejścia - Przewodnik. Warszawa; 2005.

17. Kiczka K. Administracyjne akty kwalifikujące w działalności gospodarczej. Wrocław; 2006.

18. Kieres L, Borkowski A, Kiczka K, Kocowski T, Guziński M, Szydło M. Instrumenty administracyjnoprawne w systemie oceny zgodności z zasadniczymi wymaganiami. In: Instrumenty i formy prawne działania administracji gospodarczej. Popowska B, Kokocińska K, editors. Poznań; 2009.

19. Cieśliński A, Zymonik K. Wspólnotowe prawo gospodarcze. Vol II. Cieśliński A, editor. Warszawa; 2007.

20. Urząd Ochrony Konkurencji i Konsumentów. Ogólne bezpieczeństwo produktów. www.uokik.gov.pl/ogolne_bezpieczenstwo_produktow. php (access: 1.04.2018 r.)

21. KRUS. Prewencja.znak bezpieczeństwa KRUS: https://www.krus.gov. $\mathrm{pl} /$ zadania-krus/prewencja/dzialalnosc-prewencyjna/oddzialywaniekrus-na-rzecz-wlasciwej-produkcji-i-dystrybucji-srodkowstosowanych-w-rolnictwie-oraz-sprzetu-i-odziezy-ochronnej/znakbezpieczenstwa-krus/] (access: 1.04.2020 r.)

22. KRUS. Tekst informacyjny pt.: „XVI Ogolnokrajowy Konkurs Bezpieczne Gospodarstwo Rolne. www.krus.gov.pl/zadania-krus/ prewencja/xvi-ogolnokrajowy-konkurs-bezpieczne-gospodarstworolne (access: 1.04.2020 r.)

23. KRUS. Wypadki przy pracy i choroby zawodowe rolników oraz działania prewencyjne KRUS w 2004. Warszawa; 2005.

24. KRUS. Wypadki przy pracy i choroby zawodowe rolników oraz działania prewencyjne KRUS w 2006. Warszawa; 2007.

25. KRUS. Wypadki przy pracy i choroby zawodowe rolników oraz działania prewencyjne KRUS w 2007. Warszawa; 2008.

26. KRUS. Wypadki przy pracy i choroby zawodowe rolników oraz działania prewencyjne KRUS w 2008. Warszawa; 2008.

27. KRUS. Wypadki przy pracy i choroby zawodowe rolników oraz działania prewencyjne KRUS w 2009. Warszawa; 2010.

28. KRUS. Wypadki przy pracy i choroby zawodowe rolników oraz działania prewencyjne KRUS w 2010. Warszawa; 2011.

29. KRUS. Wypadki przy pracy i choroby zawodowe rolników oraz działania prewencyjne KRUS w 2013. Warszawa; 2014.

30. KRUS. Wypadki przy pracy i choroby zawodowe rolników oraz działania prewencyjne KRUS w 2014. Warszawa; 2015.

31. Ministerstwo Rolnictwa i Rozwoju Wsi. „Bezpieczeństwo i Higiena Pracy w Gospodarstwie Rolnym”. Warszawa; 2009.

\section{Akty prawne:}

Ustawa z dnia 20 grudnia 1990 r. o ubezpieczeniu społecznym rolników, t.j. Dz. U. z 2021 r., poz.266.

Ustawa z dnia 30 sierpnia 2002 r. o systemie oceny zgodności, t.j. Dz. U. z 2017 r., poz. 1226.

Ustawa z dnia 13 kwietnia 2016 r. o systemach oceny zgodności i nadzoru rynku, Dz. U. 2017, poz. 1398.

Ustawa z dnia 16 lutego 2007 r. o ochronie konkurencji i konsumentów, t.j. Dz. U. z 2017 r., poz. 229.

Rozporządzenie Ministra Gospodarki z dn. 21 października 2008 r. w sprawie zasadniczych wymagań dla maszyn, Dz. U. z 2008 r., nr 199, poz. 1228.

Rozporządzenie Ministra Gospodarki z dnia 13 czerwca 2011 r. zmieniające rozporządzenie w sprawie zasadniczych wymagań dla maszyn, Dz. U. z 2011 r., nr 124, poz. 701.

Traktat o funkcjonowaniu Unii Europejskiej, wersja skonsolidowana Dz. Urz. UE C 326,z 26.10. 2012 P. 0001-0390.

Dyrektywa z 17 maja 2006 r. nr 2006/42/WE w sprawie maszyn zmieniająca dyrektywę 19/95/WE, Dz. U. L 157 z 9.6.2006, str. 24.

Dyrektywa Parlamentu Europejskiego i Rady 2009/127/WE z dnia 21 października 2009 r. Dz. U. L. 310 z 25.11.2009, s. 29.

Rozporządzenie Parlamentu Europejskiego i Rady (WE) nr 596/2009 z dnia 18 czerwca 2009 r. Dz. U. L 188 z 18.7.2009, s. 14.

$$
\text { Orzeczenia sądów: }
$$

II UKN 176/00 - wyrok SN - Izba Pracy z dnia 12-01-2001.

II UK 361/03 - wyrok SN - Izba Pracy z dnia 13-05-2004. 